\title{
RESPONSE OF WHEAT (TRITICUM AESTIVUM L.) CROP AND BROAD-LEAVED WEEDS TO DIFFERENT WATER REQUIREMENTS AND WEED MANAGEMENT IN SANDY SOILS
}

\author{
IBRAHIM M. EL-METWALLY ${ }^{1}$, RAMADAN. E. ABDELRAOUF ${ }^{2}$, MOHAMED A. AHMED ${ }^{3}$, \\ OUSSAMA MOUNZER ${ }^{4}$, JUAN JOSÉ ALARCÓN ${ }^{4}$, MAGDI T. ABDELHAMID ${ }^{1 *}$
}

\author{
1, 2, ${ }^{3}$ National Research Centre, Giza \\ ${ }^{4}$ CEBAS-CSIC, Murcia
}

\begin{abstract}
EL-MeTWALly, I.M. - ABDELRAOUf, R.E. - AHMED, M.A. - MOUNZER, O. - ALARCÓN, J.J. - ABDELHAMID, M.T.: Response of wheat (Triticum aestivum L.) crop and broad-leaved weeds to different water requirements and weed management in sandy soil. Agriculture (Pol'nohospodárstvo), vol. 61, 2015, no. 1, pp. 22-32.
\end{abstract}

\begin{abstract}
Water scarcity is a major cause of crops yield reduction in many parts of the world. So, a more rational use of irrigation water should be adapted and deficit irrigation principles should be accepted with a certain level of reduction in yield level. To study the efficiency of four water requirements $(100 \%$ whole season, $75 \%$ whole season, $50 \%$ whole season and $100 \%$ whole season while $50 \%$ at grain-filling stage) and five weed-control treatments (three postemergence herbicides i.e., metosulam, tribenuron-methyl, and bromoxynil), hand weeding and unweeded check, and their interactive effects, two field experiments on wheat crop were conducted in two successive seasons at the agricultural experimental station of the National Research Centre, Nubaria, Egypt. Bromoxynil, tribenuron-methyl came in the first order for con-
\end{abstract}

trolling total broad-leaved weeds. Application of $100 \%$ water requirement recorded the highest values compared to all other irrigation water treatments in term of flag-leaf area, chlorophyll content, plant height, number of spike $/ \mathrm{m}^{2}$, spike weight, grains number/spike, weight of 1,000 grains, yield and yield attributes of wheat. Metosulam followed by bromoxynil, tribenuron-methyl and hand-weeding treatments gave higher values of grain yield/ha. The highest grain yield, protein and carbohydrates percentages of wheat grains were obtained from addition of $100 \%$ water requirement with metosulam treatment was used followed by $75 \%$ of water requirement combined with metosulam treatment without significant difference among these treatments.

Key words: Bromoxynil, deficit irrigation, herbicides metosulam, tribenuron-methyl, Triticum aestivum L., weed control

Wheat is a leading food grain crop being a staple diet. It is foremost among cereals and as a main source of carbohydrates and protein for both human beings and animals; contains starch (65-75\%), protein (11-16.5\%), fat (1.5-2\%), inorganic ions $(1.2-2 \%)$ and vitamins (B-complex and E) (Rueda-Ayala et al. 2011). Wheat is the most strategic cereal crop and the main food for Egyptian people. Increasing wheat production to overcome the gap between total production and consumption could be achieved

Ibrahim M. El-Metwally: Research Professor, Botany Department, National Research Centre, 33 EL Bohouth St., Dokki, Giza, 12622, Egypt

Ramadan E. Abdelraouf: Research Associate Professor, Water Relation and Field Irrigation Department, National Research Centre, 33 EL Bohouth St., Dokki, Giza, 12622, Egypt

Mohamed A. Ahmed: Research Professor, Field Crops Research Department, National Research Centre, 33 EL Bohouth St., Dokki, Giza, 12622, Egypt

Oussama Mounzer: Irrigation Scientist, Irrigation Department, CEBAS-CSIC, Campus Universitario de Espinardo, 30100 espinardo, Apartado 164, Murcia, Spain

Juan José Alarcón: Research Professor, Irrigation Department, CEBAS-CSIC, Campus Universitario de Espinardo, 30100 espinardo, Apartado 164, Murcia, Spain

Magdi T. Abdelhamid: Research Professor (*Corresponding author), Botany Department, National Research Centre, 33 EL Bohouth St., Dokki, Giza, 12622, Egypt. E-mail: magdi.abdelhamid@yahoo.com 
by maximising the production per unit area (vertical expansion) and/or horizontal expansion through reclaiming desert lands (Mahgoub 2001). The vertical expansion could be possible via development of high-yielding varieties and simultaneously, implementing cultural practices. Moreover, in Egypt, due to the limited cultivated area, reclaiming desert lands became a must.

Agriculture water demand is one of the serious pressure on water sector in Egypt, since $85 \%$ of total available water is consumed by agriculture and most of the on-farm irrigation systems have low efficiency coupled with poor irrigation management. Water scarcity is a problem faced by Egypt these days. Therefore, irrigation water should be adequately applied to crops to prevent wastage of water. Hence, the efficiency of water use in agriculture needs to increase in a sustainable manner, that is, food production (quantitatively and qualitatively) per unit of water used has to be raised (Oweis \& Hachum 2003). In general, crop evapotranspiration (ET), and more precisely, crop transpiration is positively and linearly related to grain yield in $\mathrm{C}_{3}$ and $\mathrm{C}_{4}$ plants; therefore, water stress inevitably decreases yield (Acevedo et al. 2002). In addition, Passioura \& Angus (2010) postulated that early water stress limits tiller number and water stress after anthesis reduces the size of the individual grains and the grain number through abortion of the developing grains in wheat. Furthermore, wheat is very sensitive to high temperature (Slafer \& Satorre 1999).

Growing wheat in the new desert lands (sandy soils) would require specific cultural practices differing from those applied to the valley lands (old cultivated fertile ones). Irrigation water and weed-control treatment are the most limiting factors for wheat production in the new reclaimed area. Economic use of water is a very important problem that confronts farmers and agricultural scientist in irrigation area. This problem is becoming more acute with the increase in irrigated area. Water scarcity and low-soil fertility are the main constrains facing wheat production in the new lands in Egypt. Therefore, irrigation should be scheduled to maximise crop production per unit of applied water (Mahgoub \& Sayed 2001). Modern sprinkler irrigation system is used in the newly reclaimed sandy soils at Nubaria region, Beheira governorate, Egypt. This system improves the water use efficiency. Using chemical weed management in intensively grown crops (e.g. wheat) is easier and more economical than manual or mechanical ones, especially because of scarcity of manual labours and pay rise. But because of warnings against manipulating herbicides recently, the supply of their authorised components became extremely restricted. Weed reduced crop yield through competition for moisture, nutrients, sunlight and space. Shaban et al. (2009) reported that wheat grain yield losses due to weed interference accounted for $27.5 \%$. Moreover, during harvest and dockage, a reduction on quantity and/or quality could be happened, consequently, leading to the reduction on the economic return. Nisha et al. (1999) pointed out that reduction in wheat yield due to weed infestation has reached 30.7\%. El-Bawab and Kholousy (2003) reported that controlling weeds by herbicidal treatments increased grain yield by about 40.3 and $13.6 \%$, compared to unweeded and hand-weeding treatments, respectively. Several herbicides are available to control wheat weeds. Metosulam, tribenuron-meth$\mathrm{yl}$ and bromoxynil herbicides were introduced as selective herbicides for controlling broad-leaved weeds in cereals (El-Metwally 2002; El-Metwally et al. 2010). Application of metosulam herbicide provided $100 \%$ broad-leaved weed control and gave $20 \%$ more wheat yield than weedy check (EL-Metwally \& Saudy 2009). Tribenuron-methyl and bromoxynil are two selective herbicides for control of broad-leaved weeds in wheat (Nassar 2008).

Therefore, the main objective of this study was to examine the optimum irrigation watering regime and weed-control management to maximise the yield production of wheat under sandy soils of the new reclaimed area in Nubaria region, Egypt.

\section{MATERIAL AND METHODS}

\section{Experimental procedures}

Two field experiments were conducted during the two successive seasons (2012/13 and 2013/14) at the experimental farm of National Research Centre, Nubaria region, Egypt (latitude $30.8667 \mathrm{~N}$, and longitude $31.1667 \mathrm{E}$, and mean altitude $21 \mathrm{~m}$ above sea level). The experimental area was classified as arid region with cool winters and hot dry 
summers prevailing in the experimental area. Table 1 illustrates the monthly mean weather data for the two growing seasons 2012/13 and 2013/14, for the experimental sites in Nubaria, as obtained from the Central Laboratory of Meteorology, Ministry of Agriculture and Land Reclamation. There was no rainfall that can be taken into consideration throughout the two growing seasons. The soil of experimental site is classified as sandy soil. Some physical and chemical properties of the experimental soil are shown in Tables $2 \mathrm{a}$ and $2 \mathrm{~b}$. Irrigation water was obtained from an irrigation channel passing through the experimental area with $\mathrm{pH} 7.35$, and electrical conductivity (EC) of $0.41 \mathrm{dS} / \mathrm{m}$. The experiment was established with a split-plot design having four replicates. The main plots included four irrigation water requirements, that is, 1) $100 \%$ water requirement throughout the season, 2) $75 \%$ water requirement throughout the season, 3) $50 \%$ water requirement throughout the season, and 4) $100 \%$ water requirement throughout the season while $50 \%$ at grain-filling stage. Sub-plots were assigned to five weed-control treatments, that is, 1) Metosulam (N-2,6-dichloro-3-methyl phenyl) - 5.7 - dimethoxy - $(1,2,4)$ Triazolo $(1,5 a)$ pyrimidine -2 - sulphonamide), known commercially as
Sinal $10 \mathrm{Sc}$ sprayed after 25 days from sowing at the rate of $100 \mathrm{ml} / \mathrm{ha}, 2)$ Tribenuron-methyl (1-Methyl 2[[\{N-(4-methoxy-6-methyl-1,3,5 triazin 2-yl) methyl amino carbonyl] amino] sulfonyl]benzoate) known commercially as Granstar $75 \%$ DF sprayed after 25 days from sowing at the rate of $20 \mathrm{~L} / \mathrm{ha}$, 3) Bromoxynil (3.5-dibromo-4-hydroxybenzonitrile) known commercially as brominal $24 \%$ sprayed after 30 days from sowing at the rate of $2.5 \mathrm{~L} / \mathrm{ha}$, 4) Two hand weeding 30 and 50 days from sowing, and 5) Unweeded check. All treatments under investigation were sprayed by Clodinafop-propargyl to control the associated weed grasses of wheat. The water resource for irrigation came from an irrigation channel under rotational irrigation where water existed in the channel just for 3 days every week and the channel was empty for the remaining 4 days. The experimental field was deep ploughed before planting. First disc harrow, then duck food was used for further preparation of the field for planting. A combined driller that facilitated concurrent application of fertiliser and seeds was used. A wheat variety (Sakha 93) was planted in the first week of December in both studied seasons. The driller setting was such that it applied $167 \mathrm{~kg}$ of seed per ha, at 5 -cm soil depth with $13.5-\mathrm{cm}$ row spacing. Fertil-

$\begin{array}{llllll}\mathrm{T} & \mathrm{a} & \mathrm{b} & 1 & \mathrm{e} & 1\end{array}$

Monthly and growing season climatic data of the experimental site

\begin{tabular}{|c|c|c|c|c|c|c|c|c|}
\hline \multirow{2}{*}{ Month } & \multirow{2}{*}{$\begin{array}{l}\text { Growing } \\
\text { season }\end{array}$} & \multirow{2}{*}{$\begin{array}{c}\text { Solar } \\
\text { radiation } \\
{\left[\mathrm{W} / \mathrm{m}^{2}\right]}\end{array}$} & \multirow{2}{*}{$\begin{array}{l}\text { Precipitation } \\
{[\mathrm{mm}]}\end{array}$} & \multirow{2}{*}{ 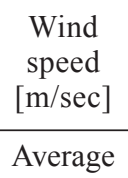 } & \multicolumn{3}{|c|}{ Air temperature $\left[{ }^{\circ} \mathrm{C}\right]$} & \multirow{2}{*}{$\begin{array}{c}\text { Relative } \\
\text { humidity } \\
{[\%]}\end{array}$} \\
\hline & & & & & Average & Min. & Max. & \\
\hline December & & 49.4 & 0.2 & 1.8 & 15.6 & 8.9 & 22.2 & 63.3 \\
\hline January & & 49.7 & 0.0 & 2.3 & 14.9 & 8.3 & 21.4 & 61.0 \\
\hline February & $2012 / 12$ & 67.5 & 0.1 & 2.1 & 16.9 & 9.3 & 24.5 & 57.7 \\
\hline March & $2012 / 13$ & 93.5 & 3.6 & 2.2 & 18.6 & 11.0 & 26.2 & 60.0 \\
\hline April & & 111.0 & 0.0 & 2.3 & 20.8 & 12.8 & 28.8 & 52.3 \\
\hline May & & 130.0 & 0.0 & 1.4 & 20.2 & 12.7 & 27.6 & 49.0 \\
\hline December & & 49.5 & 0.0 & 2.0 & 15.8 & 9.1 & 22.6 & 63.4 \\
\hline January & & 50.0 & 1.2 & 2.5 & 15.7 & 7.3 & 24.1 & 66.0 \\
\hline February & $2012 / 14$ & 68.0 & 2.6 & 2.3 & 16.8 & 7.2 & 26.4 & 56.0 \\
\hline March & $2013 / 14$ & 95.0 & 0.0 & 2.5 & 18.2 & 8.2 & 28.3 & 56.0 \\
\hline April & & 113.0 & 0.0 & 2.4 & 20.7 & 10.9 & 30.6 & 50.0 \\
\hline May & & 135.0 & 0.0 & 1.6 & 24.0 & 14.3 & 33.8 & 47.0 \\
\hline
\end{tabular}


T a b 1 e 2 a

Soil physical characteristics of experimental site

\begin{tabular}{|c|c|c|c|c|c|c|c|}
\hline \multirow{2}{*}{$\begin{array}{l}\text { Soil depth } \\
\quad[\mathrm{cm}]\end{array}$} & \multicolumn{3}{|c|}{ Particle size distribution [\%] } & \multirow{2}{*}{$\begin{array}{l}\text { Texture } \\
\text { class }\end{array}$} & \multicolumn{3}{|c|}{ Soil moisture constants } \\
\hline & Coarse sand & Fine sand & Clay + Silt & & $\begin{array}{c}\text { SP } \\
{[\%]}\end{array}$ & $\begin{array}{c}\mathrm{FC} \\
{[\%]}\end{array}$ & $\begin{array}{l}\text { WP } \\
\text { [\%] }\end{array}$ \\
\hline 20 & 57.43 & 40.08 & 2.49 & Sandy & 21.0 & 10.1 & 4.7 \\
\hline 40 & 57.02 & 39.26 & 3.72 & Sandy & 19.0 & 13.5 & 5.6 \\
\hline 60 & 56.98 & 39.18 & 3.84 & Sandy & 22.0 & 12.5 & 4.6 \\
\hline
\end{tabular}

$\mathrm{T}$ a $\quad \mathrm{b} \quad 1$ e $2 b$

Soil chemical properties of experimental site

\begin{tabular}{|c|c|c|c|c|}
\hline Soil depth $[\mathrm{cm}]$ & OM [\%] & $\mathrm{pH}(1: 2.5)$ & $\mathrm{EC}[\mathrm{dS} / \mathrm{m}]$ & $\mathrm{CaCO}_{3}[\%]$ \\
\hline 20 & 0.65 & 8.7 & 0.35 & 7.02 \\
40 & 0.40 & 8.8 & 0.32 & 2.34 \\
60 & 0.25 & 9.3 & 0.44 & 4.68 \\
\hline
\end{tabular}

$\mathrm{OM}$ - Organic matter; $\mathrm{pH}$ - acidity or alkalinity in soils; EC - electrical conductivity

isers application was based on soil analysis recommendations. All treatment plots received the same amount of total fertiliser. A compound fertiliser was applied as follow: $285 \mathrm{~kg} \mathrm{~N} / \mathrm{ha}$ as ammonium nitrate, $10 \%$ applied to the soil before planting and at tillering, the remainder being applied before each irrigation in six portions till before heading stage. $70 \mathrm{~kg} \mathrm{P}_{2} \mathrm{O}_{5} /$ ha as single superphosphate applied to the soil in two equal doses before planting and at tillering stage and $60 \mathrm{~kg} \mathrm{~K}_{2} \mathrm{O} / \mathrm{ha}$ as potassium sulphate applied once after one month from sowing.

\section{Measurements}

Weeds were hand pulled from 1 square metre of each experimental unit at 80 days after sowing (DAS), then identified and classified into broadleaved species groups. The number of weeds were recorded, then the collected weeds were first airdried in the sun and then in an electric oven for 72 hours maintaining a constant temperature of $70^{\circ} \mathrm{C}$. Consequently, the dry weights were recorded. At 90 DAS, flag-leaf area, chlorophyll content, and plant height were measured. Flagleaf area $\left[\mathrm{cm}^{2}\right]$ was measured on 10 tillers chosen randomly from each plot. The total chlorophyll content (SPAD value) of flag leaf was determined by chlorophyll meter (SPAD-502 plus) according to soil plant analysis department section, Minolta Camera Co., Osaka, Japan as reported by (Minolta Camera Co., 1989). Harvesting dates were on May $15^{\text {th }}$ and $7^{\text {th }}$ in the $1^{\text {st }}$ and $2^{\text {nd }}$ seasons, respectively, where plants of 1 square metre per each experimental plot were collected to estimate spikes number $/ \mathrm{m}^{2}$, grain and straw yields/ha. Afterward, 10 tillers were chosen randomly from each plot, and the following traits were measured: spike length, number of spikelet/spike, grain weight and grains number/spike and spike weight and weight of 1,000 grains. Total nitrogen (TN) was measured using Kjeldahl's method, and total crude protein (TCP) was determined by multiplying TN-content in grains by 6.25 according to Chapman and Pratt (1978). The phenol-sulfuric acid method was used for determination of total carbohydrates (TC) (Smith et al. 1956). Weather data recorded from an adjacent weather station. The percentage of soil moisture content $\left(\theta_{v}\right)$ was measured by profile-probe apparatus in sandy soils. 
For determination of the crop water requirements (CWR), crop evapotranspiration was calculated under standard conditions $\left(\mathrm{ET}_{\mathrm{c}}\right)$ as follows:

$\mathrm{ET}_{\mathrm{c}}=\mathrm{ET}_{\mathrm{o}} \times \mathrm{K}_{\mathrm{c}}$

where:

$\mathrm{ET}_{\mathrm{c}}=$ crop evapotranspiration $[\mathrm{mm} / \mathrm{day}]$,

$\mathrm{ET}_{\mathrm{o}}=$ reference crop evapotranspiration [mm/day], $\mathrm{K}_{\mathrm{c}}=$ crop coefficient.

The values of $\mathrm{ET}_{\mathrm{c}}$ and CWR are identical, where $\mathrm{ET}_{\mathrm{c}}$ refers to the amount of water lost through evapotranspiration and CWR refers to the amount of water that is needed to compensate for the loss. ET calculated from climatic data by directly integrating the effect of crop characteristics into $\mathrm{ET}_{0}$. The Food and Agriculture Organization of the United Nations (FAO) Penman-Monteith method is now the sole recommended as the sole standard method for calculating ETo. The Penman-Monteith equation is given by the following equation (Allen et al. 1998):

$\mathrm{ET}_{0}=\frac{0.408 \Delta\left(\mathrm{R}_{\mathrm{n}}-\mathrm{G}\right)+\gamma \frac{900}{\mathrm{~T}+273} \mathrm{u}_{2}\left(\mathrm{e}_{\mathrm{s}}-\mathrm{e}_{\mathrm{a}}\right)}{\Delta+\gamma\left(1+0.34 \mathrm{u}_{2}\right)}$

(Equation 2)

where:

$\mathrm{ET}_{0}=$ reference evapotranspiration [mm/day],

$\mathrm{R}_{\mathrm{n}}=$ net radiation at the crop surface $\left(\left[\mathrm{MJ} / \mathrm{m}^{2}\right]\right.$ per day),

$\mathrm{G}=$ soil heat flux density $\left(\left[\mathrm{MJ} / \mathrm{m}^{2}\right]\right.$ per day),

$\mathrm{T}=$ mean daily air temperature at $2 \mathrm{~m}$ height $\left[{ }^{\circ} \mathrm{C}\right]$,

$\mathrm{u}_{2}=$ wind speed at $2 \mathrm{~m}$ height $[\mathrm{m} / \mathrm{sec}]$,

$\mathrm{e}_{\mathrm{s}}=$ saturation vapour pressure $[\mathrm{kPa}]$,

$\mathrm{e}_{\mathrm{a}}=$ actual vapour pressure $[\mathrm{kPa}]$,

$\mathrm{e}_{\mathrm{s}}-\mathrm{e}_{\mathrm{a}}=$ saturation vapour pressure deficit $[\mathrm{kPa}]$,

$\Delta=$ slope of saturation vapour pressure curve at temperature $\mathrm{T}\left[\mathrm{kPa} /{ }^{\circ} \mathrm{C}\right]$,

$\gamma=$ psychrometric constant $\left[\mathrm{kPa} /{ }^{\circ} \mathrm{C}\right]$.

The equation used the standard climatological records of solar radiation (sunshine), air temperature, humidity and wind speed for daily calculations. Amount of irrigation water was calculated according to the following equation for the sprinkler irrigation system:
$\mathrm{AW}=\frac{\mathrm{ET}_{\mathrm{c}}}{\mathrm{E}_{\mathrm{a}} \times(1-\mathrm{LR})}$

(Equation 3)

where:

$\mathrm{AW}=$ applied irrigation water depth [mm/day],

$\mathrm{E}_{\mathrm{a}}=$ application efficiency equals $75 \%$ for sprinkler irrigation system,

$\mathrm{LR}=$ leaching requirements equals $10 \%$ for sprinkler irrigation system.

Irrigation time (IT) for solid sprinkler system was calculated according to equation as follows:

Irrigation time in hours (IT) $=\frac{\text { Applied irrigation water depth }}{\text { Application rate for sprinkler }}$

(Equation 4)

where:

$\mathrm{AR}=$ Application rate for sprinkler in [ $\mathrm{mm} / \mathrm{hour}]$

$\mathrm{AR}=\frac{\text { Sprinkler discharge } \times 1,000}{\text { Strip area }}$

(Equation 5)

where:

Sprinkler discharge in $\left[\mathrm{m}^{3} /\right.$ hour $]$

Strip area in $\left[\mathrm{m}^{2}\right]$

The seasonal irrigation water applied $\left[\mathrm{m}^{3} / \mathrm{ha} /\right.$ season] for 2012/13 and 2013/14, respectively are shown in Table 3.

\section{Statistical Analyses}

The combined analysis of variance for the data of the two seasons was performed after testing the error homogeneity and Fisher's Least Significant Difference $(L S D)$ test at 0.05 level obtained data from each season were subjected to the proper statistical analysis of variance of significance was used for the

T a b $\quad 1$ e 3

The seasonal irrigation water applied [ $\mathrm{m}^{3} / \mathrm{ha} /$ season] for seasons $2012 / 13$ and $2013 / 14$

\begin{tabular}{|c|c|c|}
\hline \multirow{2}{*}{ Treatment } & \multicolumn{2}{|c|}{ Growing season } \\
\cline { 2 - 3 } & $\begin{array}{c}2012 / 13 \\
{\left[\mathrm{~m}^{3} / \mathrm{ha}\right]}\end{array}$ & $\begin{array}{c}2013 / 14 \\
{\left[\mathrm{~m}^{3} / \mathrm{ha}\right]}\end{array}$ \\
\hline $100 \%$ & 4,284 & 4,382 \\
$75 \%$ & 3,220 & 3,287 \\
$50 \%$ & 2,417 & 2,191 \\
$100 \%+50 \%$ & 3,432 & 3,452 \\
\hline
\end{tabular}


comparison between means according to Gomez and Gomez (1984).

\section{RESULTS AND DISCUSSION}

\section{Weeds growth}

The experimental site was infested by broadleaved weeds where, the dominant weed flora included common wild beet (Beta vulgaris L.), lambsquarters (Chenopodium album L.) sweet clover (Melilotus indica L.) and sowthistle (Sonchus oleraceus L.).

The response of weed growth to water requirement treatments differed among weed species (Table 4). The presented results indicate that the differences among the four irrigation amounts reached the significance level in number, and dry weight of broad-leaved species and their total. In this connection, less value was obtained in plots irrigated by $50 \%$ of water requirement, while, the highest one was recorded by adding $100 \%$ of water requirement. These results are in harmony with those obtained by Bhat et al. (2006).

As shown in Table 4, all weed-control treatments were effective in reducing number and dry weight of broad-leaved species and their total compared with weedy control plots. Metosulam was the most effective herbicide than other weed-control treatments controlling each of wild beet (Beta vulgaris L.), lambsquarters (Chenopodium album L.) sweet clover (Melilotus indica L.) as well as total broadleaved weeds, while, bromoxynil significantly inhibited the number and dry weights of sowthistle (Sonchus oleraceus L.) compared to other treatments. However, the weeded treatments differed in their efficiency in weed suppression. In this respect, metosulam, bromoxynil, tribenuron-methyl and hand weeding recorded the highest efficiency in decreasing number and dry weight of total broadleaved weeds. These treatments reduced dry weight of weeds than unweeded check by 95.9, 95.8, 95.1 and $80.2 \%$, respectively. Insignificant differences were noticed among the three tested herbicides. Metosulam, bromoxynil and tribenuron are selective postemergence herbicides to control many annual broad-leaved weeds. The results of these findings may be attributed to the inhibition and deleterious effect of herbicidal treatments on weed growth, coinciding with the findings of El-Metwally and Saudy (2009), El-Metwally et al. (2010), and Shehzad et al. (2012).

T $\quad$ a

Broad-leaved weeds No. and DW $\left[\mathrm{g} / \mathrm{m}^{2}\right]$ at 80 days after sowing as influenced by watering regimes and weedcontrol treatments in wheat crop (average of two seasons 2012/13 and 2013/14)

\begin{tabular}{|c|c|c|c|c|c|c|c|c|c|c|}
\hline \multirow{2}{*}{ Treatment } & \multicolumn{2}{|c|}{ Wild beet } & \multicolumn{2}{|c|}{ Lambsquarters } & \multicolumn{2}{|c|}{ Sweet clover } & \multicolumn{2}{|c|}{ Sowthistle } & \multicolumn{2}{|c|}{ Total } \\
\hline & No. & DW & No. & DW & No. & DW & No. & DW & No. & DW \\
\hline \multicolumn{11}{|c|}{ Watering regime } \\
\hline $100 \%$ & 8.5 & 26.5 & 7.6 & 20.6 & 10.1 & 19.2 & 11.3 & 16.5 & 37.5 & 82.8 \\
\hline $75 \%$ & 7.2 & 22.4 & 6.6 & 17.9 & 8.8 & 16.7 & 10.1 & 14.7 & 32.7 & 71.7 \\
\hline $50 \%$ & 5.8 & 18.2 & 5.6 & 15.2 & 5.8 & 11.0 & 8.1 & 11.9 & 25.3 & 56.3 \\
\hline $100 \%+50 \%$ & 7.0 & 21.9 & 6.5 & 17.5 & 8.0 & 15.3 & 9.7 & 14.1 & 31.2 & 68.8 \\
\hline$L S D_{0.05}$ & 1.1 & 1.5 & 0.4 & 1.2 & 1.6 & 1.8 & 1.7 & 1.5 & 4.2 & 7.4 \\
\hline \multicolumn{11}{|c|}{ Weed control } \\
\hline Tribenuron-methyl & 1.8 & 5.6 & 1.1 & 2.9 & 1.3 & 2.6 & 1.3 & 1.9 & 5.5 & 13.0 \\
\hline Bromoxynil & 1.6 & 4.9 & 1.0 & 2.8 & 1.0 & 1.9 & 1.0 & 1.4 & 4.6 & 11.0 \\
\hline Metosulam & 1.3 & 4.0 & 0.8 & 2.3 & 0.9 & 1.7 & 1.9 & 2.8 & 4.9 & 10.8 \\
\hline Hand weeding & 5.3 & 16.5 & 5.0 & 13.6 & 6.3 & 11.9 & 6.8 & 10.0 & 23.4 & 52.0 \\
\hline Unweeded & 25.8 & 80.3 & 24.9 & 67.5 & 31.5 & 59.8 & 37.9 & 55.4 & 120.1 & 262.8 \\
\hline$L S D_{0.05}$ & 3.7 & 11.8 & 2.9 & 9.4 & 4.1 & 7.6 & 5.2 & 10.2 & 12.7 & 24.7 \\
\hline
\end{tabular}


Generally, all possible interactions among water requirement treatments and weed management had considerable impacts on dry weight of the total broad-leaved weeds as presented in Figure 1. In this regard, $50 \%$ of water requirement in plots sprayed with metosulam achieved the highest reductions in dry weight of total broad-leaved weeds, while, the highest value was recorded at $100 \%$ of water requirement treatment in unweeded plots. Similar trends were noticed by Bhat et al. (2006).

\section{Wheat growth}

Results in Table 5 reveal the significant impacts of water requirement treatments on flag-leaf area $\left[\mathrm{cm}^{2}\right]$, flag-leaf chlorophyll content (SPAD value), and plant height. In this connection, irrigation with $100 \%$ of water requirement significantly increased aforementioned traits compared to addition of $50 \%$ of water requirement. Herein, no significant differences between 100 and $75 \%$ of water requirement were found. Accordingly, supplying wheat plants with adequate water requirement might help the plant to absorb greater amount of water and nutrients, enhancing internodes elongation since nutrients encourage cell division and enlargement and meristematic activity. Besides, the beneficial effect of water for improving pigments and photosynthetic process. These results are in harmony with those ob- tained by Kassab and El-Zeiny (2005) and Tawfik et al. (2005).

Weed-control treatments significantly affected flag-leaf area, chlorophyll content and plant height (Table 5). Metosulam herbicide gave the highest

T a b 1 e 5

Effect of watering regimes and weed management on SPAD value of wheat flag leaf, plant height and yield components wheat (average of two seasons 2012/13 and 2013/14)

\begin{tabular}{|l|c|c|c|}
\hline Treatment & $\begin{array}{c}\text { Flag-leaf } \\
\text { area } \\
{\left[\mathrm{cm}^{2}\right]}\end{array}$ & $\begin{array}{c}\text { SPAD } \\
\text { (value) }\end{array}$ & $\begin{array}{c}\text { Plant } \\
\text { height } \\
{[\mathrm{cm}]}\end{array}$ \\
\hline \multicolumn{3}{|c|}{ Watering regimes } \\
\hline $100 \%$ & 42.7 & 36.2 & 73.1 \\
$50 \%$ & 41.8 & 33.8 & 71.2 \\
$100 \%+50 \%$ & 37.3 & 30.6 & 65.3 \\
$L S D_{0.05}$ & 41.3 & 32.2 & 68.7 \\
\hline \multicolumn{3}{|c|}{ Weed control } \\
\hline Tribenuron-methyl & 41.3 & 35.7 & 69.5 \\
Bromoxynil & 40.7 & 33.4 & 72.4 \\
Metosulam & 42.0 & 38.0 & 73.3 \\
Hand weeding & 42.0 & 31.2 & 68.9 \\
Unweeded & 37.3 & 28.0 & 64.0 \\
$L S D_{0.05}$ & 0.4 & 1.4 & 2.4 \\
\hline
\end{tabular}

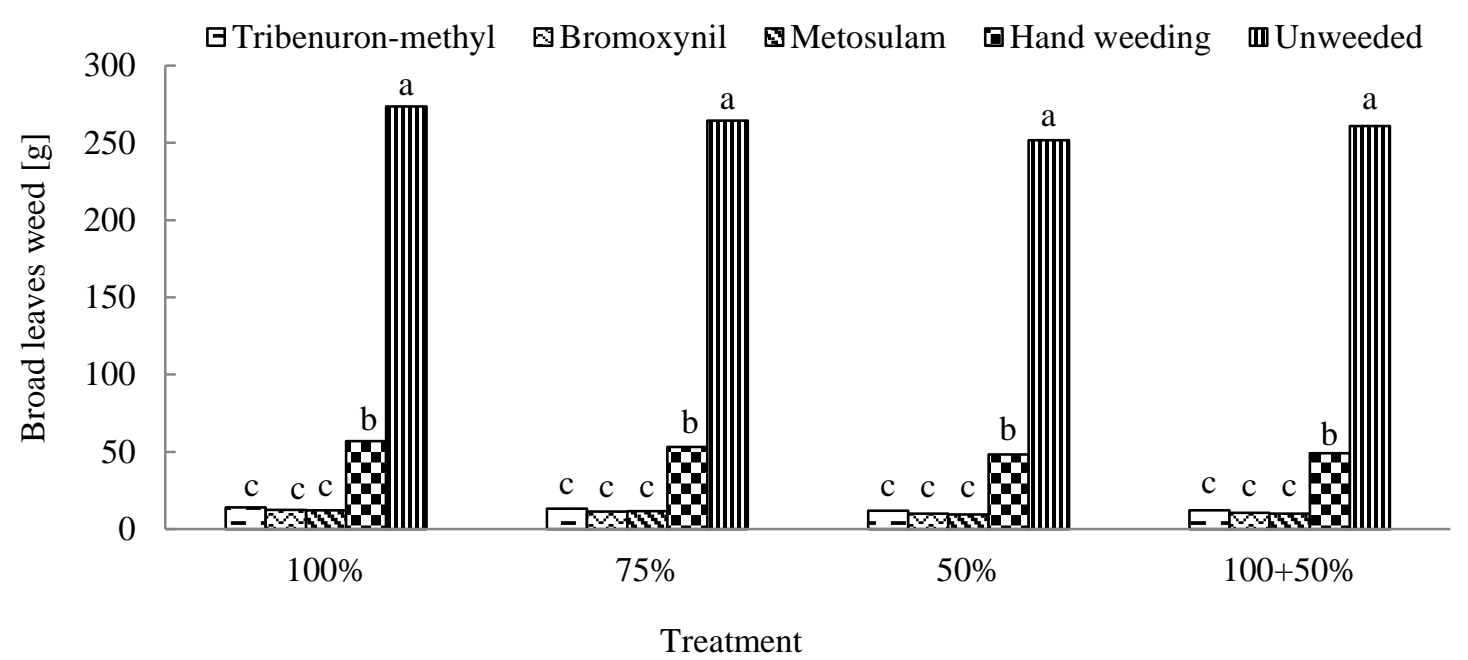

Figure 1. Interactive effects of watering regimes and weed-control treatments on total wheat broad-leaved weeds dry weights at 80 days after sowing (average of two seasons 2012/13 and 2013/14). Bars showing the same letter are not significantly different according to Fisher's Least Significant Difference $(L S D)$ test at $P \leq 0.05$. 
value of flag-leaf area, chlorophyll and plant height. The enhancement of wheat growth in the weeded plots might be attributed to the efficiency in weed elimination (Table 4), and consequently, the reduction in weed-competitive ability against wheat plants. Such conditions allow more efficient use of the environmental growth factors by crop plants reflecting on improving their growth. The results obtained are in agreement with those of Rashid and Khan (2008) and El-Metwally et al. (2010).

\section{Wheat yield and yield attributes}

Table 6 shows the significant increase in wheat yield and yield attributes with increasing level of water requirement treatment. Application of $100 \%$ of water requirement led to significant increase with maximum values of number of spike $/ \mathrm{m}^{2}$, spike weight, as well as grain weight, grains number/spike, and weight of 1,000 grains. On the other hand, the lowest value of aforementioned characteristics was obtained by adding $50 \%$ of water requirement. In this connection, addition of $100 \%$ of water requirement increased significantly grain and straw yield/ha. There was no significant difference between addi- tion of 100 and $75 \%$ watering regime on the most aforementioned traits. The decrease in yield and yield attributed due to wheat irrigation at $50 \%$ watering regime may be due to change in patterns of plant growth and development (Ouda 2006), disturbance of metabolites transportation to the grains (Kramer \& Boyer 1995), reduction in the number of reproductive tillers that limited their contribution to grain yield (Mosaad et al. 1995) and caused pollen sterility (Saini et al. 1984). So, sufficient watering regime of 100 or $75 \%$ of water requirement might help the plant to absorb greater amount of water and nutrients enhancing internodes elongation since nutrients encourage cell division and enlargement and meristematic activity (Fageria et al. 2010). Besides, the beneficial effect of water for improving pigments and photosynthetic process and accumulation of metabolites led to an increase in yield and its components. These findings confirmed previous results obtained by Mahgoub and Sayed (2001), Hefnawy and Wahba (2003), Kassab and El-Zeiny (2005), El-Sherif et al. (2007) and Ramadan and Awaad (2008). On the other situation, the highest values of no. of spike $/ \mathrm{m}^{2}$, spike weight, spike grain weight,

T $\begin{array}{lllllllllll} & \mathrm{a} & \mathrm{b} & 1 & \mathrm{e} & 6\end{array}$

Effect of watering regimes and weed management on wheat yield and yield components (average of two seasons 2012/13 and 2013/14)

\begin{tabular}{|c|c|c|c|c|c|c|c|c|c|c|c|}
\hline Treatment & $\begin{array}{l}\text { No. } \\
\text { spike/ } \\
\mathrm{m}^{2}\end{array}$ & $\begin{array}{l}\text { Spike } \\
\text { length } \\
{[\mathrm{cm}]}\end{array}$ & $\begin{array}{l}\text { No. } \\
\text { spikelet's } \\
\text { /spike }\end{array}$ & $\begin{array}{c}\text { Spike } \\
\text { weight } \\
{[\mathrm{g}]}\end{array}$ & $\begin{array}{c}\text { Spike } \\
\text { grain } \\
\text { weight } \\
{[\mathrm{g}]} \\
\end{array}$ & $\begin{array}{l}\text { No. of } \\
\text { grains } \\
\text { /spike }\end{array}$ & $\begin{array}{c}\text { 1,000-grain } \\
\text { weight }[\mathrm{g}]\end{array}$ & $\begin{array}{l}\text { Straw } \\
\text { yield } \\
{[\mathrm{t} / \mathrm{ha}]}\end{array}$ & $\begin{array}{l}\text { Grain } \\
\text { yield } \\
{[\mathrm{t} / \mathrm{ha}]}\end{array}$ & $\begin{array}{l}\text { TCP } \\
{[\%]}\end{array}$ & $\begin{array}{c}\text { TC } \\
{[\%]}\end{array}$ \\
\hline \multicolumn{12}{|c|}{ Watering regimes } \\
\hline $100 \%$ & 541.6 & 9.3 & 17.0 & 3.1 & 2.3 & 44.0 & 49.4 & 4.05 & 4.85 & 9.91 & 66.9 \\
\hline $75 \%$ & 529.5 & 8.9 & 16.5 & 3.0 & 2.2 & 41.1 & 47.6 & 3.72 & 4.53 & 9.57 & 65.9 \\
\hline $50 \%$ & 433.7 & 8.1 & 15.6 & 2.2 & 1.4 & 35.6 & 42.6 & 3.39 & 3.51 & 8.97 & 63.2 \\
\hline $100 \%+50 \%$ & 343.2 & 7.6 & 15.9 & 2.6 & 1.8 & 39.8 & 44.4 & 2.78 & 3.78 & 9.12 & 65.0 \\
\hline$L S D_{0.05}$ & 45.1 & NS & NS & 0.2 & 0.3 & 2.7 & 2.4 & 0.45 & 0.22 & 0.18 & 1.4 \\
\hline \multicolumn{12}{|c|}{ Weed control } \\
\hline Tribenuron-methyl & 489.8 & 9.0 & 17.0 & 3.1 & 2.1 & 40.8 & 46.5 & 3.59 & 4.42 & 9.39 & 65.6 \\
\hline Bromoxynil & 462.8 & 8.7 & 16.8 & 2.7 & 1.9 & 40.7 & 46.3 & 3.76 & 4.71 & 9.57 & 66.3 \\
\hline Metosulam & 516.5 & 9.9 & 17.4 & 3.3 & 2.4 & 43.5 & 48.8 & 3.82 & 5.09 & 9.77 & 67.2 \\
\hline Hand weeding & 455.3 & 8.3 & 15.5 & 2.5 & 1.7 & 38.7 & 45.8 & 3.43 & 3.59 & 9.14 & 64.4 \\
\hline Unweeded & 385.7 & 7.3 & 14.6 & 2.3 & 1.4 & 37.0 & 42.8 & 2.82 & 3.34 & 9.09 & 62.8 \\
\hline$L S D_{0.05}$ & 54.7 & NS & NS & 0.5 & 0.1 & 0.2 & 1.9 & 0.21 & 0.24 & 0.15 & 1.6 \\
\hline
\end{tabular}

TCP - total crude protein; TC - total carbohydrates 
as well as grains number/spike, and weight of 1,000 grains were gained with metosulam treatment was applied. Contrariwise, the lowest ones were produced from the unweeded check (Table 5). Metosulam followed by bromoxynil, tribenuron-methyl and hand-weeding treatments gave higher values of grain yield/ha. They significantly increased grain yield/ha over the unweeded check by $52.4,41.0$, 32.3 and $7.5 \%$, respectively. Such superior-weeded treatments minimised weed-crop competition (Table 4) and saved more available environmental resources for crop plants that improved growth traits (Table 5). This, in turn, increased flag-leaf area at heading stage, and plant height and produced more assimilates synthesised, translocated, and accumulated in various plant organs that positively reflected on straw and grain yields/ha. The positive effect of weeded practices on wheat yields and its com- ponents have been confirmed by El-Metwally and El-Rokiek (2007), Rueda-Ayala et al. (2011) and Shehzad et al. (2012).

\section{Wheat grains chemical composition}

Averages of TCP\% and TC\% were appreciably influenced by water requirement treatments as shown in Table 6. In this respect, with each increase in water amount, there was a progressive increase in TCP $\%$ and TC\%. Application of $100 \%$ water requirement recorded the highest value of TCP $\%$ and $\mathrm{TC} \%$. On the other side, the lowest $\mathrm{TCP} \%$ and $\mathrm{TC} \%$ were recorded with $50 \%$ water requirement. Similar trend was found by other authors (Kassab and El-Zeiny 2005; Tawfik et al. 2005; El-Sherif et al. 2007). As shown in Table 6, all tested weed-control treatments significantly improved $\mathrm{TCP} \%$ and $\mathrm{TC} \%$ of wheat grains. The highest TCP\% and TC\% were

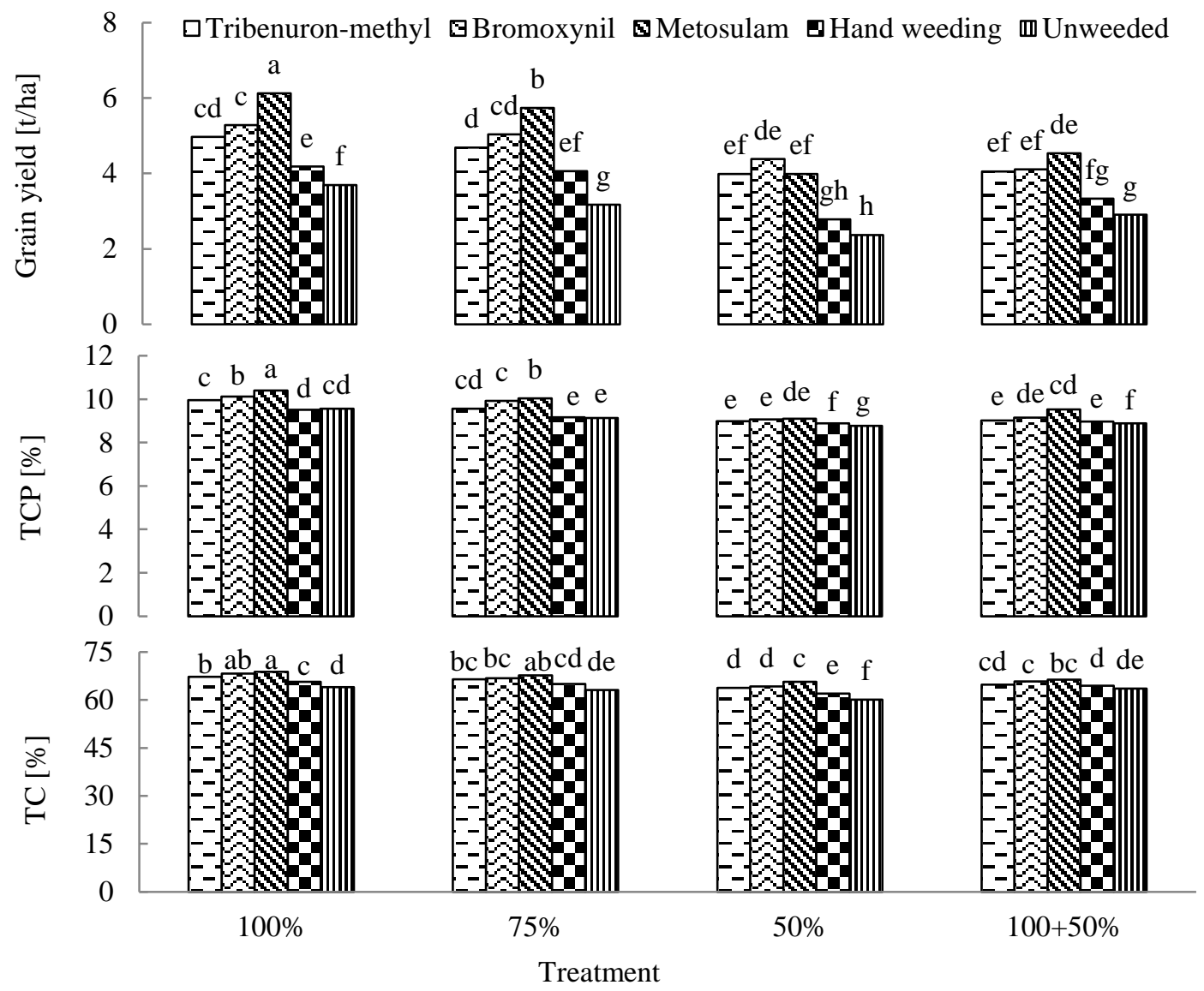

Figure 2. Interactive effects of watering regimes and weed-control treatments on wheat grain yield, chemical composition of $\mathrm{TCP} \%$ (total crude protein percentage), and TC\% (total carbohydrates percentage) at harvest (average of two seasons 2012/13 and 2013/14). Bars showing the same letter are not significantly different according to Fisher's Least Significant Difference $(L S D)$ test at $P \leq 0.05$. 
obtained from metosulam treatment. These results may be due to the less competition for nutrients, water and light through limiting weeds infestation with herbicidal and hand-hoeing treatments due to increasing uptake of different nutrients. In contrast, the lowest statistical values of aforementioned traits showed in the unweeded treatment. Similar results were obtained by several authors (El-Metwally \& Saudy 2009; El-Metwally et al. 2010; Shehzad et al. 2012). Figure 2 shows a significant interaction between water requirement and weed-control treatments on $\mathrm{TCP} \%$ and $\mathrm{TC} \%$ of wheat grains. The highest grain $\mathrm{TCP} \%$ and $\mathrm{TC} \%$ were obtained from addition of $100 \%$ of water requirement with metosulam treatment, followed by $75 \%$ of water requirement combined with metosulam treatment without significant difference among these treatments. On the other hand, the lowest grain $\mathrm{TCP} \%$ and $\mathrm{TC} \%$ were recorded under the unweeded treatment with $50 \%$ of water requirement. These results confirm those obtained by Bhat et al. (2006).

\section{CONCLUSIONS}

It could be concluded that increasing water requirement significantly increased number and dry weight of wheat weeds at 80 days after sowing. Metosulam herbicide at $100 \mathrm{ml} /$ ha provided potential control with $96 \%$ reduction in total broad-leaved weeds dry weight at 80 days after sowing. Application of $100 \%$ of water requirement recorded the highest growth, yield and yield attributes of wheat. Metosulam herbicides followed by bromoxynil, tribenuron-methyl and hand-weeding treatments gave higher grain yield/ha. The highest grain yield, TCP and TC percentages of wheat grains were obtained under addition of $100 \%$ of water requirement combined with metosulam treatment followed by $75 \%$ of water requirement combined with metosulam treatment without significant difference between both treatments.

Acknowledgements. This work was part of the Research Project No. 10120110 supported by the National Research Centre, Cairo, Egypt.

\section{REFERENCES}

ACEVEDO, E. - SILVA, P. - SILVA, H. 2002. Wheat growth and physiology. In CURTIS, B.C. (Ed.) Bread Wheat: Improvement and Production, FAO Plant Production and Protection Series No. 30. Rome, Italy, 2002. p. 567. Available from: <http://www.fao.org/docrep/006/ y4011e/y4011e06.htm $>$ (last access 19.03.2015).

ALLEN, R.G. - PEREIRA, L.S. - RAES, D. - SMITH, M. 1998. Crop evapotranspiration - Guidelines for computing crop water requirements - FAO Irrigation and drainage paper 56. FAO - Food and Agriculture Organization of the United Nations, Rome.

BHAT, M.A. - MAHAL, S.S. - HUSSAIN, A. - MUSHKI, G.M. 2006. Effect of nitrogen levels, irrigation regimes and weed management in durum wheat (Triticum durum Desf.). In Indian Journal of Crop Science, vol. 1, no. 1-2, pp. 184-188.

CHAPMAN, H.D. - PRATT, R.F. 1978. Methods analysis for soil, plant and water. University of California Div. Agric. Sci. pp. 16-38.

EL-METWALLY, I.M. 2002. Performance wheat cultivars and associated weeds to some weed control treatments. In Zagazig Journal of Agricultural Research, vol. 29, pp. 1907-1927.

EL-METWALLY, I.M.-EL-ROKIEK, K.G. 2007. Response of wheat plants and accompanied weeds to some new herbicides alone or combined in sequence. In Arab Universities Journal of Agricultural Sciences, vol. 15, pp. 513-525.

EL-METWALLY, I.M. - SAUDY, H.S. 2009. Herbicides tank- mixtures efficiency on weeds and wheat productivity. In Annals of Agricultural Science, Moshtohor, vol. 47, pp. 95-109.

EL-METWALLY, I.M. - ABD EL-SALAM, M.S. TAGOUR, R.M.H. 2010. Nitrogen fertilizer levels and some weed control treatments effects on barley and associated weeds. In Agriculture and Biology Journal of North America, vol. 1, pp. 992-1000.

EL-BAWAB, A.M.O. - KHOLOUSY, A.O. 2003. Effect of seeding rate and method of weed control on the productivity of Giza 2000, a promising barley line, under new lands condition. In Egyptian Journal of Agricultural Research, vol. 81, pp. 1085-1098.

EL-SHEREF, E.M. - OMAR, A.M. - EL-HAG, A.A. SHAHEN, A.M. 2007. Effect of some agricultural treatments on barley yield and some technological characters. In Journal of Agricultural Science, Mansoura University, vol. 32, pp. 1671-1690.

FAGERIA, N.K. - BALIGAR, V.C. - JONES, C.A. 2010. Growth and Mineral Nutrition of Field Crops. Third Edition. CRC Press, Taylor \& Francis Group, 586 pp. ISBN 9781439816950.

GOMEZ, K.A. - GOMEZ, A.A. 1984. Statistical Procedures for Agriculture Research. A Wiley - Inter Science Publication, John Wiley \& Sons, Inc., New York, USA. $680 \mathrm{pp}$

HEFNAWY, F.A. - WAHBA, M.F. 2003. Effect of water stress in late growth stages of some wheat cultivars. In Journal of Agricultural Science, Mansoura University, vol. 28, pp. 729-745. 
KASSAB, O.M. - EL-ZEINY, H. 2005. Effect of water stress and paclobutrazol application on growth and yield of wheat plants. In Journal of Agricultural Science, Mansoura University, vol. 30, pp. 1881-1888.

KRAMER, P.J. - BOYER, J.S.1995. Water relationship of plants and soils. Academic Press, San Diego. 495 p.

MAHGOUB, A.A.S. 2001. Quantitative determination of the gene action of stripe, stem and leaf rust resistance in A 6-parent daiallel cross of wheat. In Journal of Agricultural Science, Mansoura University, vol. 26, pp. 147-155.

MAHGOUB, H.S. - SAYED, M.A. 2001. Response of two wheat cultivars to irrigation amount and nitrogen level in sandy soils. In Journal of Agricultural Science, Mansoura University, vol. 26, pp. 1863-1873.

MOSAAD, M.G. - ORTIZ-FERRARA, G. - MAHALAKSHMI, V. 1995. Tiller development and contribution to yield under different moister regimes in two Triticum species. In Journal of Agronomy and Crop Science, vol. 174, pp. 173-180. DOI: 10.1111/j.1439037X.1995.tb01100.x.

MINOLTA CAMERA CO. 1989. Manual for chlorophyll meter SPAD-502. Minolta Camera Co., Osaka, Japan.

NASSAR, A.N.M. 2008. Response of two barley varieties to mineral and biological nitrogenous fertilizer and weed control treatments. In Journal of Agricultural Science, Mansoura University, vol. 33, pp. 29-51.

NISHA, C. - HARPAL, S. - TRIPATHI, H.P. - CHOPRA, N. - SINGH, H. 1999. Critical period of weed crop competition in wheat (Triticum aestivum L). In Indian Journal of Weed Science, vol. 31, pp. 151-154.

OWEIS, T. - HACHUM, A.Y. 2003. Improving water productivity in the dry areas of west Asia and north Africa. In KIJNE, J.W. - BARKER, R. - MOLDEN, D. (Eds.) Water productivity in agriculture: limits and opportunities for improvement. CAB International. pp. 179-198.

OUDA, S.A. 2006. Predicting the effect of water and salinity stresses on wheat yield and water needs. In Journal of Applied Sciences Research, vol. 2, pp. 750-756. http://www.aensiweb.com/old/jasr/jasr_ october_2006.html.

PASSIOURA, J.B. - ANGUS, J.F. 2010. Improving productivity of crops in water-limited environments. In Advances in Agronomy, vol. 106, pp. 37-75.
RAMADAN, A.R. - AWAAD, S.S. 2008. Response of yield and yield attributes of some bread wheat varieties to irrigation levels and seeding rate under old land conditions. In Journal of Agricultural Science, Mansoura University, vol. 33, pp. 4717-4737.

RASHID, A. - KHAN, R.U. 2008. Comparative effect of varieties and fertilizer levels on barley (Hordeum vulgare). In International Journal of Agriculture and Biology, vol. 10, no. 1, pp. 124-126. http://www. fspublishers.org/published_papers/20955_..pdf.

RUEDA-AYALA, V.P. - RASMUSEM, J. - GERHARDS, R. - FOURNAISE, N.E. 2011. The influence of post emergence weed harrowing on selectivity, crop recovery and crop yield in different crop stages of winter wheat. In Weed Research, vol. 51, 478-788. DOI: $10.1111 / \mathrm{j} .1365-3180.2011 .00873 . x$.

SAINI, H.S. - SEDGLEY, M. - SPINALL, D.A. 1984. Development anatomy in wheat of male sterility by induced by heat stress. Water deficit or abscisic acid. In Australian Journal of Plant Physiology, vol. 11, pp. 243-254. DOI:10.1071/PP9840243.

SHABAN, S.A. - SOLIMAN, S. - YEHIA, Z.R. - EL ATTAR, M.H. 2009. Weed competition effects on some Triticum aestivum quality and quantity components. In Egyptian Journal of Agronomy, vol. 31, pp. 135-147.

SHEHAZD, M.A. - NADEEM, M.A. - IQBAL, M. 2012. Weed control and yield attributes against postemergence herbicides application in wheat crop, Punjab, Pakistan. In Global Advanced research Journal of Agricultural Science, vol. 1, pp. 7-16.

SLAFER, G.A. - SATORRE, E.H. 1999. Wheat: Ecology and physiology of yield determination. Haworth Press Technology and Industrial, pp. 322-323. ISBN 1-56022-874-1.

SMITH, F. - GILlES, M.A. - HAMILTON, J.K. GODEES, P.A. 1956. Colorimetric method for determination of sugar related substances. In Analytical Chemistry, vol. 28, pp. 350-356.

TAWFIK, M.M. - EL-KRAMANY, M.F. - BAHR, A.A. 2005. A comparative study on the effect of water stress at different reproductive stages of growth of four wheat cultivar. In Egyptian Journal of Agricultural Research, vol. 2, pp. 243-255.

Received: February 2, 2015 